\title{
Mustasotilaskärpäsen toukkajauhon (Hermetia illucens) aminohappojen sulavuus porsailla
}

\author{
Kirjoittajat: Tiina Kortelainen ${ }^{1)}$, Hilkka Siljander-Rasi ${ }^{2)}$, Mikko Tuori ${ }^{3)}$, Kirsi Partanen ${ }^{4)}$ \\ 1) Luonnonvarakeskus, Vihreä teknologia, PL 18,01301Vantaa tiina.kortelainen@luke.fi \\ 2) Luonnonvarakeskus, Vihreä teknologia,PL 18,01301Vantaa hilkka.siljander-rasi@luke.fi \\ 3) Luonnonvarakeskus, Vihreä teknologia, PL 18, 01301 Vantaa \\ 4) Nykyinen osoite: Snellmanin Lihanjalostus Oy, Kuusisaarentie 1, 68600 Pietarsaari
}

\section{TIIVISTELMÄ}

ICOPP -tutkimushankkeessa tehdyn kokeen tavoitteena oli määrittää luonnonmukaisesti tuotetun, EU:ssa sioille toistaiseksi kielletyn eläinperäisen rehuaineen, mustasotilaskärpäsen (Hermetia illucens) toukista valmistetun jauhon, aminohappojen standardoitu ohutsuolisulavuus porsailla. Jauhot oli tuotettu FiBL -luomututkimuslaitoksessa Sveitsissä. Kokeessa oli kaksi hiilihydraattipohjaisella alustalla kasvatettua toukkaerää, joista ensimmäisessä rasva oli erotettu mekaanisesti, toisessa heksaaniuutolla. Koe-eläiminä oli 40 risteytysporsasta (alkupaino $17 \mathrm{~kg}$ ) pariruokinnalla. Koeruokintoja oli viisi: 1) vähäproteiininen rehu aminohappojen endogeenisen perustason erityksen määritystä varten, 2) rehu, jossa oli erän 1 toukkajauhoa 10,2 \%, 3) rehu, jossa oli erän 1 toukkajauhoa $20,4 \%$, 4) rehu, jossa oli erän 2 toukkajauhoa $9,3 \%$ ja 5) rehu, jossa oli erän 2 toukkajauhoa 18,6 \% rehun kuiva-aineessa (KA). Ryhmien 2-5 rehuissa oli lisäksi heravalkuaisjauhetta 22,9 \% rehun KA:ssa. Kokeen lopussa siat lopetettiin aminohappojen ohutsuolisulavuuden määrittämistä varten. Erän 1 toukkajauho sisälsi $629 \mathrm{~g}$ raakavalkuaista, $185 \mathrm{~g}$ raakarasvaa, $318 \mathrm{~g}$ NDF ja $51 \mathrm{~g}$ tuhkaa/kg KA. Vastaavat arvot toisen erän toukkajauholle olivat 705 g, 90 g, 287 ja 53 g/kg KA. Hyönteisten sisältämä kuitu on selluloosaa muistuttavaa kitiiniä ja siihen sitoutuneen typen (ADF-N) käyttökelpoisuus on huono. Kokeen toukkajauhojen kokonaistypestä noin $12 \%$ oli ADF-typpeä. Erän 1 toukkajauhossa oli $31,7 \mathrm{~g}$ lysiiniä, 24,3 g treoniinia, $12,0 \mathrm{~g}$ metioniinia, 3,5 g kystiiniä ja $39,6 \mathrm{~g} / \mathrm{kg}$ KA valiinia. Vastaavat arvot toisen erän toukkajauholle olivat $37,8 \mathrm{~g}, 27,4 \mathrm{~g}, 14,1 \mathrm{~g}, 3,7 \mathrm{~g} \mathrm{ja} \mathrm{44,2} \mathrm{g} / \mathrm{kg}$ KA. Toukkaerä, toukkajauhon lisäystaso tai porsaiden sukupuoli eivät vaikuttaneet koedieettien aminohappojen näennäiseen ohutsuolisulavuuteen (AID). Mekaanisesti erotetun toukkajauhon (erä 1) standardoidut (SID) aminohappojen ohutsuolisulavuudet olivat suurempia verrattuna heksaaniuutettuun toukkajauhoon (erä 2). Välttämättömien aminohappojen SID oli ensimmäisessä toukkajauhoerässä $81,3-94,8 \%$ ja toisessa toukkajauhoerässä $64,0-81,8 \%$. Lysiinin standardoitu ohutsuolisulavuus oli ensimmäisessä toukkajauhoerässä 81,3\%, metioniinin 90,7 \%, kystiinin 49,8\%, treoniinin $82,5 \%$ ja valiinin $92,9 \%$. Vastaavat sulavuudet toisessa toukkajauhoerässä olivat 77,2 \%, $81,8 \%,-10,8 \%, 64,0 \%$ ja 73,6 \%. Mustasotilaskärpäsen toukkien käyttö valkuaisrehuna edellyttää rasvan erottamista, koska toukat sisältävät noin $380 \mathrm{~g}$ raakarasvaa/kg ka. Mekaaninen rasvan erotus on aminohappojen sulavuudelle edullisempi kuin heksaaniuutto. Kitiiniin sitoutunut käyttökelvoton typpi on huomioitava ruokinnan suunnittelussa. Kalajauhoon verrattuna toukkajauhossa on vähemmän välttämättömiä aminohappoja ja niiden sulavuus on huonompi. Toukkajauhon tuotannon kannattavuutta tulisi selvittää.

\section{Asiasanat:}

Sika, porsas, mustasotilaskärpänen, Hermetia illucens, toukka, ohutsuolisulavuus, aminohapot 


\section{Johdanto}

Ruoantuotannossa on monia haasteita nykypäivänä, kuten maailman jatkuvasti kasvava populaatio, ylikulutus, ilmastonmuutokset ja uusiutumattomien luonnonvarojen loppuminen. Lihankulutus kasvaa, mikä puolestaan lisää tarvetta uusille valkuaislähteille tuotantoeläinten ruokinnassa. Hyönteisiä käytetään jo lemmikkieläinten rehuihin ja hyönteisiä käytetään myös ihmisravinnoksi monissa maissa. EU:n lainsäädäntö ei vielä salli tuotantoeläinten ruokkimista hyönteisistä saatavalla eläinperäisellä prosessoidulla valkuaisella (processed animal protein, PAP). Hyönteisistä peräisin olevaa rasvaa kuitenkin saa käyttää yksimahaisten ruokinnassa. Hyönteisjauholle ei ole mitään kategoriaa rehuaineluettelossa (Catalogue of Feed Materials (EC 68/2013)), mutta listaus on olemassa kokonaisille maalla eläville selkärangattomille tai niiden osille, joten hyönteisperäinen valkuainen saattaisi olla mahdollinen raaka-aine tuotantoeläinten ruokinnassa. Monia epäselviä kohtia on vielä auki. Näitä ovat mm. sallittujen epäpuhtauksien, kuten raskasmetallien, maksimipitoisuudet ja tuotantokäytännöt, joilla saadaan hyönteisistä PAP:ia.

BSE-tapausten vuoksi säädökset (EC 999/2001) kielsivät kaiken PAP:n käytön (hydrolysoitu valkuainen on poikkeus) eläinten rehuksi. Poikkeus tehtiin 2013 kalanrehun kohdalla, ja eimärehtijöistä peräisin olevaa PAP:ia voidaan käyttää kasvatetuille kaloille, jotka päätyvät ihmisravinnoksi. Tämä säädös koskee teurastamon prosessointia ja koska hyönteisillä ei ole samanlaista teurastusprosessia hyönteisistä peräisin oleva PAP on kielletty. Hyönteiset, joita kasvatettaisiin PAP tuotantoa varten, olisivat "kasvatettuja eläimiä" ja lainsäädäntö asettaa vaatimuksia niiden ruokinnalle. Bioetanolituotannon sivutuotteet ( $\mathrm{mm}$. vehnäproteiini ja ohrankuoret) löytyvät rehuaineluettelosta (Catalogue of feed materials (EC 68/2013), ja niitä voitaisiin käyttää hyönteisten kasvualustana. Lanta sitä vastoin on kategoriassa "ei saa käyttää tuotantoeläinten rehuna".

Huonekärpäsen toukat voivat vähentää lanta-alustan massaa $60 \%$ kymmenessä päivässä, mikä olisi hyödyllistä myös ympäristölle. Kasviperäinen jäte, kotitalousjäte ja lanta olisivat ekologisesti käyttökelpoisia jätteitä hyönteisten kasvattamiseen (Koeleman 2014). Hyönteisistä saatavan PAP:n käyttö tuotantoeläinten ruokinnassa on keskustelussa EU:ssa.

Sekä huonekärpänen, että sotilaskärpänen sisältävät laadukasta valkuaista, jonka on todettu tukevan broilerien normaalia kasvua. Osa raakavalkuaisesta on kitiinimuodossa, mikä on yksimahaisille eläimille käyttökelvotonta (Finke 2007). Sotilaskärpäsen toukassa on vähemmän valkuaista ja enemmän rasvaa kuin huonekärpäsen toukassa. Sotilaskärpäsen toukkia on myös helpompi kasvattaa sen koon vuoksi (Newton ym. 1977). Mustasotilaskärpäsen toukkien tuotannossa eduksi on se, että se menestyy hankalissa olosuhteissa (kuivuus, niukka ravinto ja hapenpuute) ja aikuinen mustasotilaskärpänen ei syö, joten se ei tarvitse erityistä hoitoa eikä se levitä tauteja. Toukat jopa muokkaavat lannan mikrobistoa mahdollisesti jopa alentaen haitallisten bakteerien, kuten E. colia ja Salmonellaa. On jopa esitetty, että toukat sisältäisivät luonnollista antibioottia. Toukat kuitenkin vaativat lämpimät olosuhteet, mikä voi nostaa kasvatuksen kustannuksia. Elinkierto vaihtelee useista viikoista useisiin kuukausiin riippuen lämpötilasta ja ravinnon laadusta ja määrästä. Mustasotilaskärpäsen toukat sisältävät n. 40-44 \% raakavalkuaista ja paljon rasvaa (15-49\%). Rasvan määrä ja laatu on riippuvainen toukkien ravinnosta. Tuhkapitoisuus on melko korkea, mutta vaihteleva (11-28 \%). Toukat sisältävät paljon lysiiniä (6-8 \% raakavalkuaisesta). Toukkien kuiva-ainepitoisuus on melko korkea 35-45 \%, jonka vuoksi ne on helppo kuivata. Toukissa on metioniinia, kystiiniä ja treoniinia kuitenkin niin vähän, että niitä tulee lisätä sikojen rehuun muista rehuaineista tasapainoisen ravitsemuksen aikaansaamiseksi. Toukkarehut ovat yhtä maittavia kuin soijarouhepohjaiset rehut (Makkar ym. 2014). Newton ym. (1977) ehdottavat, että Hermetia -jauho on sopiva rehuraaka-aine sioille, erityisesti sen aminohappokoostumuksen ja kalsiumpitoisuuden ansiosta. Heidän mukaansa 33 \%:n lisäystaso, jota he kokeessaan käyttivät, saattaa olla liian suuri, ja Hermetia jauhoa voitaisiin paremmin hyväksikäyttää pienemmillä lisäysmäärillä sioille.

Tämän ICOPP-hankkeen tutkimuksen tavoitteena oli määrittää mustasotilaskärpäsen toukista (Hermetia illucens) tehdyn jauhon aminohappojen standardoitu ohutsuolisulavuus (standardised ileal digestibility SID) kasvavilla sioilla. 


\section{Aineisto ja menetelmät}

\section{Koe-eläimet, koemalli ja koerehut}

Hermetia -toukkajauho tuli Sveitsistä FiBL:stä (Research Institute of Organic Agriculture, Switzerland) ja se oli tuotettu hiilihydraattipohjaisella, luonnonmukaisella rehulla. Ensimmäisessä erässä rasva oli erotettu mekaanisesti, toisessa erässä heksaaniuutolla. Jauho tutkittiin salmonellan varalta . Kokeessa oli yhteensä 40 vieroitettua 40-49 pv:n ikäistä Risteytys!! n. 17 kiloista (alkupaino) porsasta, joita ruokittiin kahdesti päivässä. Porsaat olivat kahden porsaan karsinoissa, joissa sahanpurua käytettiin kuivikkeena, paitsi kokeen lopussa muutamaa päivää ennen teurastusta kuivikkeet poistettiin ja luiset virikelelut annettiin tilalle. Kokeessa huomioitiin, että osa hyönteisen typestä on kiinni kitiinissä, ja siten käyttökelvottomassa muodossa sioille. Tämä ADF-N osa vähennettiin toukkajauhon kokonaistypen määrästä ja dieetit suunniteltiin sisältämään samat määrät typpeä, joka ei ole peräisin ADF-typestä. Koeryhmiä oli 5:

1) vähäproteiininen rehu aminohappojen endogeenisen perustason erityksen määritystä varten

2) $89,8 \%$ tärkkelyspohjainen dieetti, jossa 22,85\% WPC + 10,2\% Hermetia jauhoa erästä 1.

3) 79,6 \% tärkkelyspohjainen dieetti, jossa $22,85 \%$ WPC + 20,4\% Hermetia jauhoa erästä 1 .

4) 90,7 \% tärkkelyspohjainen dieetti, 22,85\% WPC + 9,3\% Hermetia jauhoa erästä 2 .

5) 81,4\% tärkkelyspohjainen dieetti, jossa 22,85 \% WPC + 18,6 \% Hermetia jauhoa erästä 2 .

Tärkkelyspohjaiset rehut sisälsivät samoja rehuraaka-aineita kuin vähäproteiininen rehu, mutta raakavalkuaisen määrä oli $160 \mathrm{~g} / \mathrm{kg} \mathrm{KA}$, mikä saavutettiin lisäämällä rehuun heravalkuaistiivistettä (WPC) ja vähentämällä $\mathrm{mm}$. ohratärkkelyksen määrää. Osa tästä tärkkelyspohjaisesta rehusta korvattiin Hermetia -jauholla (erän 1 tai 2 jauho koeryhmän mukaan). Tärkkelyspohjainen rehu ja Hermetia -jauho punnittiin erikseen ja sekoitettiin. Rehunvaihdot tehtiin portaittain. Viimeinen jakso (2) eli varsinainen koevaihe kesti 8 pv. Titaanidioksidia käytettiin rehuissa merkkiaineena $(3 \mathrm{~g} / \mathrm{kg}$ KA). Rehuista otettiin näytteet jakson 2 lopussa.

Kokeen lopussa (koepäivä 18) siat ruokittiin porrastetusti ja lopetettiin 3,5 tunnin kuluttua viimeisestä ruokinnasta. Vatsaontelo avattiin ja ruokasulaa kerättiin ohutsuolesta $(\mathrm{n} .50-60 \mathrm{~cm}$ matkalta ohutsuolen ja umpisuolen liitoksesta taaksepäin) aminohappojen ohutsuolisulavuuden määrittämistä varten. Titaniumdioksidia käytettiin rehussa merkkiaineena (3 g/ $\mathrm{kg} \mathrm{KA})$. Ruokasulanäytteet pakastettiin ja niistä analysoitiin kuiva-aine, tuhka, aminohapot ja merkkiaine. Koerehujen analysoitu kemiallinen koostumus on esitetty taulukossa 1 sivulla 4.

\section{Sulavuuslaskut ja analyysit}

Dieettien aminohappojen näennäinen ohutsuolisulavuus (AID) laskettiin merkkiaineen avulla. Perustason aminohappojen endogeeninen eritys (g/ kg KA) laskettiin Steinin ym. (2007) mukaan ohutsuolen ruokasulan näytteistä niiltä porsailta, jotka söivät vähäproteiinista rehua. Aminohappojen standardoitu ohutsuolisulavuus laskettiin Steinin ym. (2007) mukaan. Kahden erilaisen Hermetia jauhon, sekä perusrehun aminohappojen AID ja SID arvot laskettiin regressiomenetelmällä (Fan ja Sauer 1995) käyttämällä SAS GML proseduuria. Dieettien AID arvot laskettiin MIXED proseduuria käyttäen ja kiinteitä tekijöitä olivat Hermetia erä, lisäystaso ja porsaiden sukupuoli. Yhdysvaikutuksia mitattiin Hermetia erän ja lisäystason välillä, Hermetia erän ja porsaiden sukupuolen välillä ja lisäystason ja porsaiden sukupuolen välillä. 
Taulukko 1. Koerehujen analysoitu kemiallinen koostumus, g/kg KA.

\begin{tabular}{|c|c|c|}
\hline & $\begin{array}{c}\text { Tärkkelyspohjainen } \\
\text { vähäproteiininen } \\
\text { rehu }\end{array}$ & $\begin{array}{l}\text { Tärkkelys- } \\
\text { pohjainen } \\
\text { rehu }^{1}\end{array}$ \\
\hline Kuiva-aine, g/kg & 913 & 927 \\
\hline Tuhka & 40 & 28 \\
\hline Raakavalkuainen & 32 & 107 \\
\hline \multicolumn{3}{|c|}{ Aminohapot, g/kg KA } \\
\hline \multicolumn{3}{|c|}{ Välttämättömät } \\
\hline Arginiini & 0,8 & 2,6 \\
\hline Histidiini & 0,9 & 2,4 \\
\hline Isoleusiini & 1,9 & 7,1 \\
\hline Leusiini & 3,4 & 12,4 \\
\hline Lysiini & 2,8 & 10,3 \\
\hline Metioniini & 1,3 & 3,2 \\
\hline Fenyylialaniini & 1,2 & 3,9 \\
\hline Treoniini & 2,1 & 7,9 \\
\hline Valiini & 1,7 & 6,8 \\
\hline \multicolumn{3}{|l|}{ Ei-välttämättömät } \\
\hline Alaniini & 1,5 & 5,6 \\
\hline Asparagiinihappo & 3,5 & 12,7 \\
\hline Kystiini & 0,6 & 2,1 \\
\hline Glutamiinihappo & 5,4 & 20,0 \\
\hline Glysiini & 0,7 & 2,3 \\
\hline Proliini & 1,9 & 6,8 \\
\hline Seriini & 1,7 & 6,0 \\
\hline Tyrosiini & 0,9 & 3,2 \\
\hline \multicolumn{3}{|c|}{${ }^{2}$ Käytettiin Hermetia jauhon kanssa. } \\
\hline \multicolumn{3}{|c|}{ Ryhmä 2: $898 \mathrm{~g} / \mathrm{kg} \mathrm{KA}$ tärkkelyspohjaista rehua $+102 \mathrm{~g} / \mathrm{kg}$ KA Hermetia jauhoa erästä 1} \\
\hline \multicolumn{3}{|c|}{ Ryhmä 3: 796 g/kg KA tärkkelyspohjaista rehua +204 g/kg KA Hermetia jauhoa erästä 1} \\
\hline \multicolumn{3}{|c|}{ Ryhmä 4: $907 \mathrm{~g} / \mathrm{kg}$ KA tärkkelyspohjaista rehua + 93 g/kg KA Hermetia jauhoa erästä 2} \\
\hline \multicolumn{3}{|c|}{ Ryhmä 5: $814 \mathrm{~g} / \mathrm{kg} \mathrm{KA}$ tärkkelyspohjaista rehua $+186 \mathrm{~g} / \mathrm{kg} \mathrm{KA}$ Hermetia jauhoa erästä 2} \\
\hline
\end{tabular}

\section{Tulokset}

Hermetia jauhon analysoitu kemiallinen koostumus on esitetty taulukossa 2. Mekaanisesti käsitelty (erä 1) Hermetia jauho sisälsi enemmän rasvaa (185 g/kg KA) kuin heksaaniuutettu (erä 2) $(90 \mathrm{~g} / \mathrm{kg}$ KA). Erä 1 sisälsi hiukan vähemmän raakavalkuaista kuin erä 2 (629 ja 705 g/kg KA) ja siten myös vähemmän aminohappoja. Glutamiinihapon pitoisuus oli paljon alhaisempi erässä 1 verrattuna erään 2 (64,7 ja 73,0 g/kg KA). Molemmissa erissä kitiiniin sitoutuneen, eli käyttökelvottoman typen osuus (ADF-N) oli $12 \mathrm{~g} / \mathrm{kg} \mathrm{KA}$. 
Taulukko 2. Hermetia jauhon analysoitu kemiallinen koostumus, g/kg KA.

\begin{tabular}{lcc}
\hline Kuiva-aine g/kg & $\begin{array}{c}\text { Hermetia jauho } \\
\text { mekaaninen } \\
\text { erotus }\end{array}$ & $\begin{array}{c}\text { Hermetia } \\
\text { jauho } \\
\text { heksaani-uutto }\end{array}$ \\
\hline Tuhka & 925 & 906 \\
Raakavalkuainen & 51 & 53 \\
Raakarasva & 629 & 705 \\
NDF & 185 & 90 \\
ADF & 318 & 287 \\
ADF-N ${ }^{1}$ & 136 & 143 \\
Aminohapot, g/kg KA & 12 & 12 \\
Välttämättömät & & \\
Arginiini & & 32,0 \\
Histidiini & 30,5 & 20,8 \\
Isoleusiini & 18,4 & 30,8 \\
Leusiini & 26,9 & 49,5 \\
Lysiini & 43,5 & 37,8 \\
Methioniini & 31,7 & 14,1 \\
Fenyylialaniini & 12,0 & 28,0 \\
Treoniini & 24,1 & 27,4 \\
Valiini & 24,3 & 44,2 \\
Ei-välttämättömät & 39,6 & \\
Alaniini & & 45,6 \\
Asparagiinihappo & 39,6 & 63,5 \\
Kystiini & 57,4 & 3,7 \\
Glutamiinihappo & 3,5 & 73,0 \\
Glysiini & 64,7 & 40,4 \\
Proliini & 34,3 & 41,2 \\
Seriini & 36,3 & 30,1 \\
Tyrosiini & 27,1 & 43,8 \\
\hline 1ADF-N Ty, & \\
\hline
\end{tabular}

${ }^{1} \mathrm{ADF}-\mathrm{N}=$ Typpi tässä muodossa on eläimelle käyttökelvottomassa muodossa.

Aminohappojen standardoitu ohutsuolisulavuus (SID) on esitetty taulukossa 3. Perusrehun ja Hermetia jauhon aminohappojen SID arvot laskettiin regressiomenetelmällä. Mekaanisesti erotetun Hermetia jauhon (erä 1) standardoidut (SID) aminohappojen ohutsuolisulavuudet olivat suurempia verrattuna heksaaniuutettuun Hermetia jauhoon (erä 2). Välttämättömien aminohappojen SID oli ensimmäisessä Hermetia jauhoerässä 81,3 - 94,8 \% ja toisessa Hermetia jauhoerässä 64,0 - 81,8 \%. Kystiinin standardoitu ohutsuolisulavuus oli melko alhainen ensimmäisessä Hermetia erässä $(49,8 \%)$ ja toisen erän Hermetia jauholla kystiinin SID oli negatiivinen. 
Taulukko 3. Standardoidut aminohappojen ohutsuolisulavuudet kahdessa erilaisessa Hermetia jauhoerässä.

\begin{tabular}{|c|c|c|c|c|}
\hline & \multicolumn{2}{|c|}{$\begin{array}{c}\text { Hermetia jauho } \\
\text { mekaaninen rasvan } \\
\text { erotus }\end{array}$} & \multicolumn{2}{|c|}{$\begin{array}{c}\text { Hermetia } \\
\text { jauho rasvan } \\
\text { heksaani-uutto }\end{array}$} \\
\hline & $\begin{array}{c}\text { Keski- } \\
\text { arvo }\end{array}$ & SEM & Keskiarvo & SEM \\
\hline $\mathrm{n}$ & 16 & & 16 & \\
\hline \multicolumn{5}{|l|}{ Välttämättömät } \\
\hline Arginiini & 94,3 & 10,71 & 78,6 & 7,96 \\
\hline Histidiini & 84,4 & 13,41 & 73,0 & 8,53 \\
\hline Isoleusiini & 93,2 & 11,26 & 76,7 & 8,42 \\
\hline Leusiini & 94,8 & 12,48 & 76,1 & 9,15 \\
\hline Lysiini & 81,3 & 16,81 & 77,2 & 10,22 \\
\hline Methioniini & 90,7 & 12,65 & 81,8 & 7,75 \\
\hline Fenyylialaniini & 94,2 & 12,41 & 80,4 & 7,52 \\
\hline Treoniini & 82,5 & 19,38 & 64,0 & 11,73 \\
\hline Valiini & 92,9 & 11,73 & 73,6 & 8,88 \\
\hline \multicolumn{5}{|l|}{ Ei-välttämättömät } \\
\hline Alaniini & 90,4 & 12,55 & 76,1 & 8,65 \\
\hline Asparagiinihappo & 83,7 & 16,50 & 59,6 & 10,28 \\
\hline Kystiini & 49,8 & 62,51 & $-10,8$ & 28,44 \\
\hline Glutamiinihappo & 75,3 & 25,43 & 64,9 & 15,00 \\
\hline Glysiini & 78,8 & 19,56 & 56,9 & 15,67 \\
\hline Proliini & 86,3 & 13,34 & 72,9 & 8,70 \\
\hline Seriini & 86,4 & 17,60 & 69,8 & 9,77 \\
\hline Tyrosiini & 100,7 & 13,51 & 65,1 & 11,40 \\
\hline
\end{tabular}

$\mathrm{n}=$ eläinten $\mathrm{lkm}$

SEM=keskiarvon keskivirhe

\section{Tulosten tarkastelu}

Tämän kokeen Hermetia toukat oli kasvatettu hiilihydraattipohjaisella alustalla. Tuhka- ja rasvapitoisuus olivat hiukan erilaisia verrattuna Kyntäjän ym. (2014) raportin lihaluujauholla ja kotitalousjätteellä (ei sallittuja kasvatusalustoja) kasvatettuihin toukkiin, joista rasva oli eroteltu (tuhka 168 ja rasva43 g/kg KA lihaluujauhoalustalla, 137 ja $20 \mathrm{~g} / \mathrm{kg}$ kotitalousjätealustalla ja tässä kokeessa mekaanisesti erotetussa erässä 51 ja $185 \mathrm{~g} / \mathrm{kg} \mathrm{KA}$ ja heksaaniuutetulla erällä 53 ja $90 \mathrm{~g} / \mathrm{kg}$ KA). Raakavalkuaispitoisuus oli hyvin samankaltainen lihaluujauhoalustalla kasvatetuilla toukilla ja tämän kokeen mekaanisesti erotetulla toukkaerällä (627 ja 629 g/kg KA, vastaavasti). Tämän kokeen heksaaniuutetun toukkaerän raakavalkuaispitoisuus oli suurempi (705 g/kg KA) kuin edellä mainitut sekä kotitalousjätealustalla kasvatettujen toukkien raakavalkuaispitoisuus (659 g/kg KA). Välttämättömien aminohappojen pitoisuudet olivat hyvin samankaltaisia kaikkien kasvatusalustojen kesken (Kyntäjä ym. 2014). De Marco ym. (2015) tutkivat Hermetia illucens jauhon näennäistä ohutsuolisulavuutta (apparent ileal digestibility, AID) broilereilla. Kyseisessä tutkimuksessa Hermetia jauhossa oli raakavalkuaista vain $369 \mathrm{~g} / \mathrm{kg}$ KA. Tässä kokeessa Hermetia jauhossa oli huomattavasti enemmän raakavalkuaista (mekaanisesti erotellussa erässä 629 ja heksaaniuutetussa erässä $705 \mathrm{~g} / \mathrm{kg}$ KA). Aminohappojen pitoisuudet olivat siten myös hyvin paljon korkeammat, kystiiniä lukuun ottamatta, tässä kokeessa verrattuna de Marcon ym. (2015) kokeeseen. De Marcon ym. (2015) kokeessa Hermetia jauhon välttämättömien aminohappojen pitoisuudet olivat 9,05-24 g/kg KA ja tässä kokeessa pitoisuudet olivat $12-49,5 \mathrm{~g} / \mathrm{kg} \mathrm{KA}$. Kystiinin pitoisuus kuitenkin oli tässä kokeessa vain 3,6 g/kg KA, kun de Marcon ym. (2015) kokeessa se oli 13,8 g/kg KA.

Tutkimuksia Hermetia jauhon sulavuudesta sioilla ei ole saatavilla. De Marcon ym. (2015) broilerikokeessa välttämättömien aminohappojen keskimääräinen näennäinen ohutsuolisulavuus broilereilla oli $64 \%$. Tässä kokeessa keskimääräinen välttämättömien aminohappojen AID sioilla oli huomattavasti korkeampi. Mekaanisesti erotetussa toukkajauhoerässä välttämättömien aminohappojen AID oli $88 \%(79,3$ - 93,2) \% ja heksaaniuutetussa toukkajauhoerässä $74 \%(61,2-79,9) \%$. 
Tässä tutkimuksessa käytetyn Hermetia jauhon raakavalkuaispitoisuus oli verrattavissa kalajauhon taulukkoarvoihin. Heksaaniuutetun Hermetia jauhon raakarasvapitoisuus oli verrattavissa kalajauhon arvoihin, mutta mekaanisesti erotetun Hermetia jauhon raakarasvapitoisuus oli korkeampi kuin kalajauhossa. Tuhkapitoisuus, sekä lysiini- ja metioniinipitoisuudet olivat Hermetia jauhossa kalajauhoa matalampia, kun taas treoniinipitoisuus oli lähellä kalajauhon arvoja. Hermetia jauhon kystiinipitoisuus oli selvästi matalampi ja valiinipitoisuus selvästi korkeampi kuin kalajauhossa (CVB 2011, EvaPig 2008). NDF pitoisuuden perusteella arviolta noin kolmasosa Hermetia jauhosta on kitiiniä.

Mekaanisesti erotetun Hermetia jauhon lysiinin ja treoniinin standardoitu ohutsuolisulavuus oli jokin verran alhaisempi, verrattuna kalajauhon rehutaulukkoarvoihin, mutta arginiinin, metioiniinin, isoleusiinin, valiinin, leusiinin, fenyylialaniinin ja histidiinin arvot olivat samankaltaisia kuin kalajauhon tai jopa korkeampia (CVB 2011, EvaPig 2008). Kun Hermetia jauhon aminohappojen sulavuuksia verrattiin kasviperäiseen valkuaiseen, huomataan, että mekaanisesti erotetun Hermetia jauhon lähes kaikkien välttämättömien aminohappojen, paitsi treoniinin ja histidiinin, standardoitu ohutsuolisulavuus oli korkeampi kuin soijarouheella. Arginiinin SID oli soijarouheen kaltainen. Mekaanisesti erotetun Hermetia jauhon standardoidut aminohappojen ohutsuolisulavuudet ovat yleisesti ottaen korkeampia kuin herneellä (CVB 2011, EvaPig 2008). Kuitenkin, Hermetia jauhon kystiinin ohutsuolisulavuus on hyvin alhainen.

\section{Johtopäätökset}

Rasvanerotusmenetelmä vaikuttaa Hermetia jauhon aminohappojen näennäiseen ja standardoituun ohutsuolisulavuuteen, sillä sulavuusarvot olivat alhaisempia heksaaniuutetulla Hermetia jauholla verrattuna mekaanisesti eroteltuun Hermetia jauhoon. Tulokset osoittavat, että Hermetia jauho, jossa rasva on mekaanisesti erotettu, tarjoaa hyvin sulavia aminohappoja, jotka voivat parantaa porsaiden luomurehujen aminohappotasapainoa. Hermetia jauho voisi monipuolistaa luomutuotannon valkuaislähteitä, mutta Hermetia jauhon tuottamisen taloudellisia näkökulmia pitää vielä tutkia.

\section{Kirjallisuus}

CVB 2011. Chemical compositions and nutritional values of feed materials. Centraal Veevoederbureau: Lelystad, The Netherlands.

De Marco, D., Martínez, S., Hernandez, F., Madrid, J., Gai, F., Rotolo, L., Belforti, M., Bergero, D., Katz, H., Dabbou, S., Kovitvadhi, A., Zoccarato, I., Gasco, L. \& Schiavone, A. 2015. Nurtitional value of two insect larval meals (Tenebrio molitor and Hermetia illucens) for broiler chickens: Apparent nutrient digestibility, apparent ileal amino acid digestibility and apparent metabolizable energy. Animal feed Science and Technology 209: 211-218.

EC 68/2013 http://eur-lex.europa.eu/LexUriServ/LexUriServ.do?uri=OJ:L:2013:029:0001:0064:EN:PDF sivut $10,17 \mathrm{ja} 48$.

EC 999/2001http://ec.europa.eu/food/fs/afs/marktlab/marktlab14 en.pdf

EvaPig 2008. EvaPig® Evaluation of Pig feeds. Energy, amino acids and phosphorus values for pigs. INRA, AFZ, Ajinomoto Eurolysine S.A.S. Viitattu 20.11.2014 www.evapig.com

Fan, M.Z., Sauer, W.C. 1995. Determination of Apparent ileal amino acid digestibility in peas for pigs with the direct, difference and regression method. Livestock Production Science 44:61-72.

Finke, M.D. 2007. Estimate of Chitin in Raw Whole Insects. Zoo Biology 26: 105-115.

Koeleman, E. 2014. Insects crawling their way into feed regulation. All About Feed. 22 (6):18-21.

Kyntäjä, S., Partanen, K., Siljander-Rasi, H., Jalava, T. 2014. Tables of composition and nutritional values of organically produced feed materials for pigs and poultry. MTT Report 164 (2014). 37 p. ISBN 978-952-487-571-4. Available at: http://jukuri.mtt.fi/bitstream/handle/10024/484922/mttraportti164.pdf

Makkar, H. P.S., Tran, G., Heuzé, V. ja Ankers, P. 2014. Review State-of-the-art on use of insects as animal feed. Animal Feed Science and Technology 197: 1-33.

Newton, G.L., Booram, C.V., Barker, R.W. and Hale, O.M. 1977. Dried Hermetia illucens Larvae Meal as a Supplement for Swine. Journal of Animal Science 44, 395-400.

Stein, HH., Sève, B., Fuller, MF., Moughan, PJ., de Lange, CFM. 2007. Invited review: Amino acid bioavailability and digestibility in pig feed ingredients: Termonology and application. Journal of Animal Science 85:172-180. 